\title{
CULTURAL DIFFERENCES IN FOOD CONSUMPTION: THE EXPERIENCES OF INTERNATIONAL STUDENTS
}

\author{
Nikolett Németh \\ Szent István University, Doctoral School of Management and Business Administration, Gödöllő, Hungary \\ e-mail: nikolett_nemeth@hotmail.com
}

\begin{abstract}
There is a great variety of foods eaten. It is obvious that foods play a very important role in the daily lives of individual nations. Foods and meals, however, serve not only the living, but also fulfil other functions in the given society. For example, food expression may be part of a social class, reveal income conditions, and express identity.

The investigation was carried out on the topic by a qualitative method, in the form of an in-depth interview. The interviews were conducted by master students of the Szent István University in the framework of Multicultural Management subject, with non-Hungarian origin. A total of 65 in-depth interviews were conducted between 2017 and 2018. Interviewees were members of 22 nationalities. During the investigations, the main questions were: What type of food do you consume the most? What factors do you take into consideration when choosing foods? What differences do you find in the habits of the different ethnic groups, especially with regard to their eating habits? Most of the interviewees are interested in compare their diet and cultural traditions to other nations' and prefer local foods. The study proved that eating habits in Hungary have an impact on the eating habits of foreign students, and they change them in several elements. The study found that dietary choices are a complex decision that has a significant environmental and social impact but need to say, thanks to the strong cultural background the students can keep their sustainable eating values in abroad.
\end{abstract}

Keywords: culture, food choice, consumption

\section{INTRODUCTION}

Several authors [1] [2] have already studied the role of food in the economy and society. Meals and food are an integral part of our daily lives, creating a bond between people. In his study Nagy [2] pointed out that this point of view shows how food creates a shared world view among those who share the same culture.

The role of food and food in culture is evidenced by the fact that in 2014, the Mediterranean diet was added to the repertoire of UNESCO's intellectual heritage of humanity. The list (in a complex way) describes the diet as a combination of crops, harvesting, fishing, animal husbandry, processing, cooking, and especially sharing and consuming food. Mediterranean diet also emphasizes the importance of hospitality, neighborhood, intercultural dialogue and creativity, and draws attention to respect for diversity and the fact that meals are never just about nutrition [2].

Consumer behaviour is becoming increasingly heterogeneous due to cultural differences. This phenomenon makes it increasingly important to understand the impact of national cultures and their impact on consumer behaviour. To understand consumer behaviour, we need to study how individuals, groups, and organizations meet their needs and needs, choose, buy, use, and utilize products, services, ideas, or experiences.

The study of consumer behaviour is based on an analysis of observable behaviours:

- who, what, how much and how they bought

- how the product was consumed,

- individual needs, perceptions

- what information consumers have and how they process them

- how to evaluate alternatives

- how they feel about owning a product

DOI: 10.14232/analecta.2019.1.56-63 


\section{Analecta Technica Szegedinensia}

Food consumer behaviour occupies a special place within consumer behaviour in several respects: on the one hand, it is directly or indirectly related to the survival of man, and on the other is the result of long biological, social and cultural processes, and thirdly the most complex human behaviour. There are several contradictions in the consumer behaviour of the food. Characterized by a paradox: Consumption of food is a source of human well-being and discomfort equally. Food consumed is the basis for health, but it can also cause disease. Another contradiction is the dual behaviour, which can be characterized by different contradictory pairs: simple-complex, biological-psychological, average-unique, general-special, individualcorporate, casual-festive, planned-random, and so on. There is interest in new foods and fear of the new in food consumer behaviour.

The models of food consumer behaviour are built on three components:

- on the one hand, the food itself, along with the physical, chemical and biological properties that trigger physiological effects and needs,

- on the other hand, the customer, the person of the consumer, who perceives food and the surrounding environment through sensory perception, psychological factors,

- thirdly, an economic and social environment that is an external condition for the consumer [3].

Many models of cultural differences were studied in literature. The purpose of cultural models is to make the individual elements and the they can be used to compare the cultures studied and draw conclusions about dominant values [4].

When examining the economic factors that influence food consumer behaviour, it is primarily the incomes and prices that must be taken into account, as well as the structure of consumer spending. Income affects food consumption in several ways: on the one hand its size, its structure, the breadth and depth of its choice. For example, the share of food in the expenditure structure of older people is higher. In this age group, the need to preserve health and reduce the risks associated with nutrition is particularly appreciated. However, domestic experience shows that older people - because they have weaker purchasing power prefer lower-priced, less valuable food [3].

In the case of sociological factors, consumer behaviour is strongly influenced by all the groups to which the individual is a member or of which he or she wants to be a member [1].

The family is a special group that is a collective decision-making and business community. Food choices are based on family traditions, the individual's eating habits are acquired by the family and will have a decisive impact on life. Households are the consumers of most products, and many members of the household can make their decision to buy a product. The family also plays a significant role in the development of nutritional habits and a healthy lifestyle. Opinion leaders are those who, in informal communication, provide advice or information about a product or product group, how many brands, which brand is best, or how the product can be used [4]. In the case of foods, doctors, athletes, nutrition advisors play a role as opinion leaders, who usually exert their influence on the flow of information within informal groups. Psychological factors determine the individual's acceptance or rejection of certain foods, or the weight or role of accepted foods [4]. Among the psychological factors influencing consumer behaviour, the personality, activating factors (motivation, attitude) and cognitive factors have to be examined. Activating needs are linked to an individual's internal tension and act on the consumer's behaviour through the following connection system: Emotion $\rightarrow$ Motivation $\rightarrow$ Attitude $\rightarrow$ Behaviour.

Biological factors provide consumers with the energy resources they need to function and the building elements of their body during their nutrition. Another outstanding biological function of nutrition is that it affects the senses. Nutrition, in addition to being an indispensable function, carries a threat. Nutrition appears as a source of danger due to inappropriate nutrition or consumed food.

Another problem is that, instead of natural foods, the consumption of semi-finished or finished products produced by the industry has come to the fore, unilateral consumption of which does not provide full nutrition. There are cases where some of the diseases caused by food consumed have a negative effect in a short time (such as food infections, food allergies). 


\section{Analecta Technica Szegedinensia}

Nutrition can also be responsible for a disease not directly caused by a particular food, such as illnesses caused by inappropriate lifestyle and eating habits (vascular diseases, diabetes, cancerous diseases). Nutrition problems are also reflected in the values of the Hungarians' health.

Cultural / Anthropological Factors: Culture According to Hofmeister-Tóth (2003), it is "the totality of the learned beliefs, values, and habits that guide consumers' behaviour in a given society." [5] Values, value systems, as carriers of cultural features, help the individual to choose a behavioural pattern that matches his personality traits. Values and lifestyles are highly determinative of human core behaviour and thus of consumer behaviour. However, different values for different consumers may have different meanings, such as social values (love, family), religion, money, beauty, youth, etc. [4]

According to Lehota (2001), culture is the most complex, decisive concept and relationship among factors influencing food consumption. The essence of which is that it is the result of a learning process, shared features by the society and the members of the group, which originate from the past and contain components that are inherited by generations, as a combination of components shared by social institutions. [1] Szakály et al stated [6] that the level of culture evaluation can be country group, country / nation, region, ethnicity. Culture, as an environmental factor, determines what counts and classifies food in a given society: holy food-everyday food, food as medicine, and food as a symbol of group and individual identity. In my study, I demonstrate the role played by the elements of culture in food consumption, what differences can be observed in the food consumption of different populations, and that how cultural factors such as value, religion, traditions, ceremonies, etc. affect eating habits. I present a qualitative research method to show the role of food consumption in the culture of several ethnic groups and to introduce how cultural factors influence the eating habits. The research is devoted to exploratory research, which provides a good basis for later quantitative research.

\section{MATERIALS AND METHODS}

My study was conducted in the form of a qualitative method by means of in-depth interview. The research is intended for exploratory research that provides a good basis for future quantitative research.

The interviews were conducted by the graduates of Szent István University's foreign and Hungarian leadership and organization in the framework of the Multicultural Management course with persons of non-Hungarian origin. A total of 65 in-depth interviews were conducted between 2017 and 2018. The language of the interviews was different, based on the language of the interviewee who was best able to communicate with the interviewer. In most cases, this was English. The length of the interviews was on average 50 minutes, and the length and language of the transcripts were very varied. As it is a qualitative research, we used qualitative methods: content analysis. Demographic data were quantified where possible. The persons interviewed came from 22 nationalities, most of them named Hungary as their current residence at the time of the interview. Interviewees who did not live in Hungary were typically Skype or telephone interviews.

The interview was conducted based on an interview guide. Audio interviews, transcripts and translations were made of the interviews. Table 1 shows the structure of the interview. This study does not cover all the topics examined in the interviews; it is limited to only one part that we consider important. 


\section{Analecta Technica Szegedinensia}

Table 1. Structure and Purpose of the Interview Scheme

\begin{tabular}{|c|c|}
\hline Sections & Goals \\
\hline I. The aim of the research & $\begin{array}{l}\text { Presentation of the purpose of the research, informing } \\
\text { the participants, providing anonymity, recording }\end{array}$ \\
\hline II. Introduction & $\begin{array}{l}\text { Obtaining demographic data (age, nationality, residence, } \\
\text { family, friends, leisure) }\end{array}$ \\
\hline III. Consumer habits & $\begin{array}{l}\text { Main food types, frequency of consumption, diet of } \\
\text { special diet, special foods, way of preparing food, } \\
\text { ceremonies, food role }\end{array}$ \\
\hline IV. Food choice & $\begin{array}{l}\text { Influence factors, quality, label, risks, traditional vs. new } \\
\text { foods }\end{array}$ \\
\hline V. Culture and food consumption & $\begin{array}{l}\text { Interpretation of the concept of culture, values, ethnic } \\
\text { groups, travel, relationships, cultural knowledge }\end{array}$ \\
\hline VI. Summary and conclusion & Summary of thoughts, deduction of conclusions \\
\hline
\end{tabular}

\section{RESULTS AND DISCUSSION}

\subsection{Characterization of the sample}

The interviewees were members of several ethnic groups (Figure 1); most of the people came from Germany (7 people), China (6 people) and from the neighbouring country: Poland (5 persons), Romania (5 persons), Slovakia (5 persons).

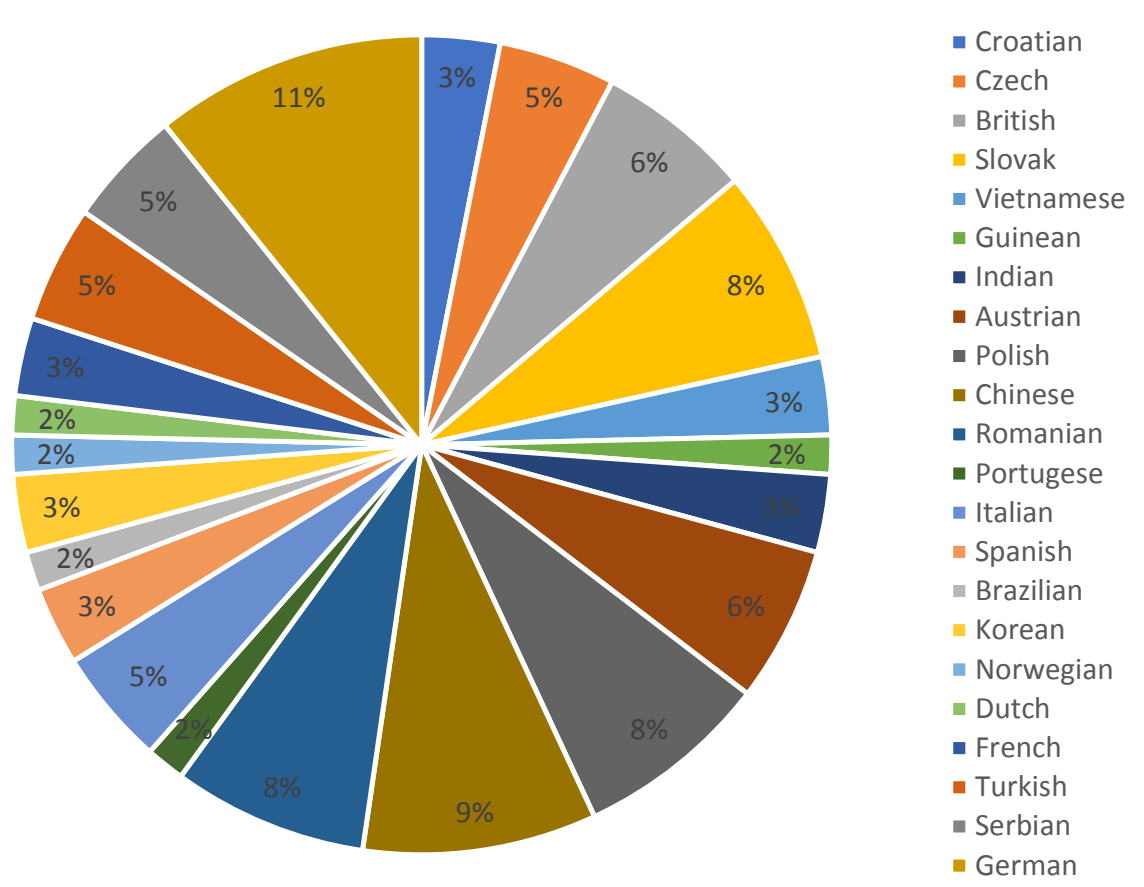

Figure 1. The distribution of participants based on nationalities, percent 


\section{Analecta Technica Szegedinensia}

Regarding the gender ratio, the majority of the interviewees were men (70\%), while the ratio of women participated in the interviews was $30 \%$.

Figure 2 shows the frequency of people participating in the interviews by age group. It turns out that the majority of the interviewees come from the 18-29 age group, and the 30-39 age group is also represented in large numbers.

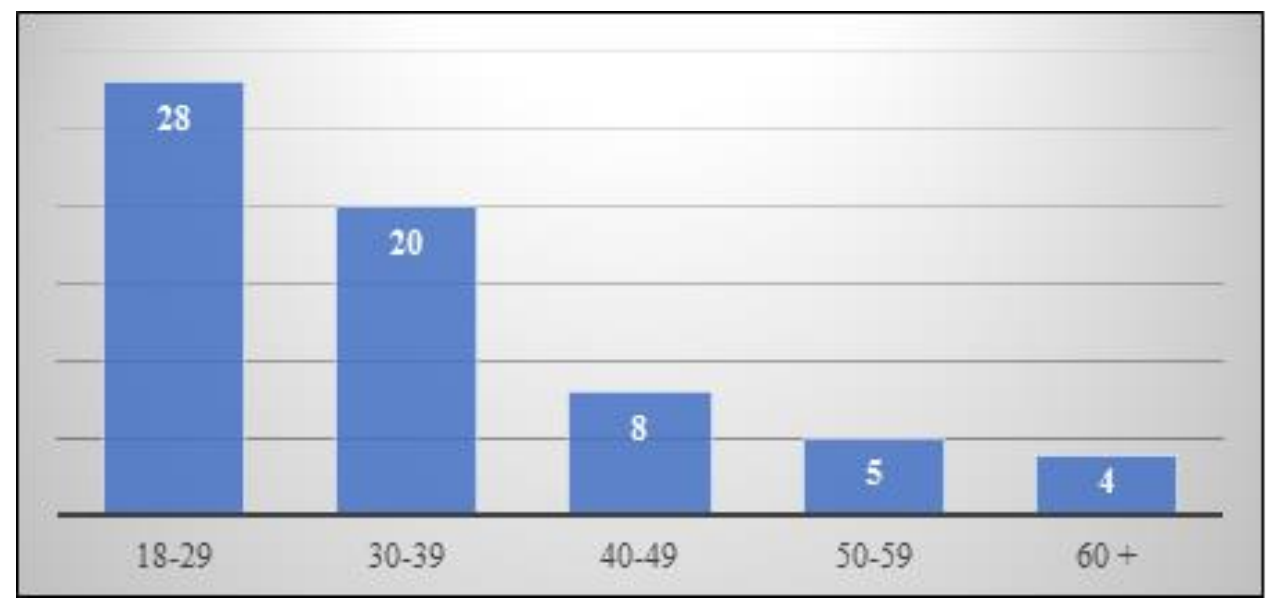

Figure 2. The number of participants based on age, persons on nationalities, percent

I was also curious about the current location of the participants. As it is shown in Figure 3., the vast majority of interviewees stayed in Hungary at the time of the interview. Rest of the participants stayed at other European destinations.

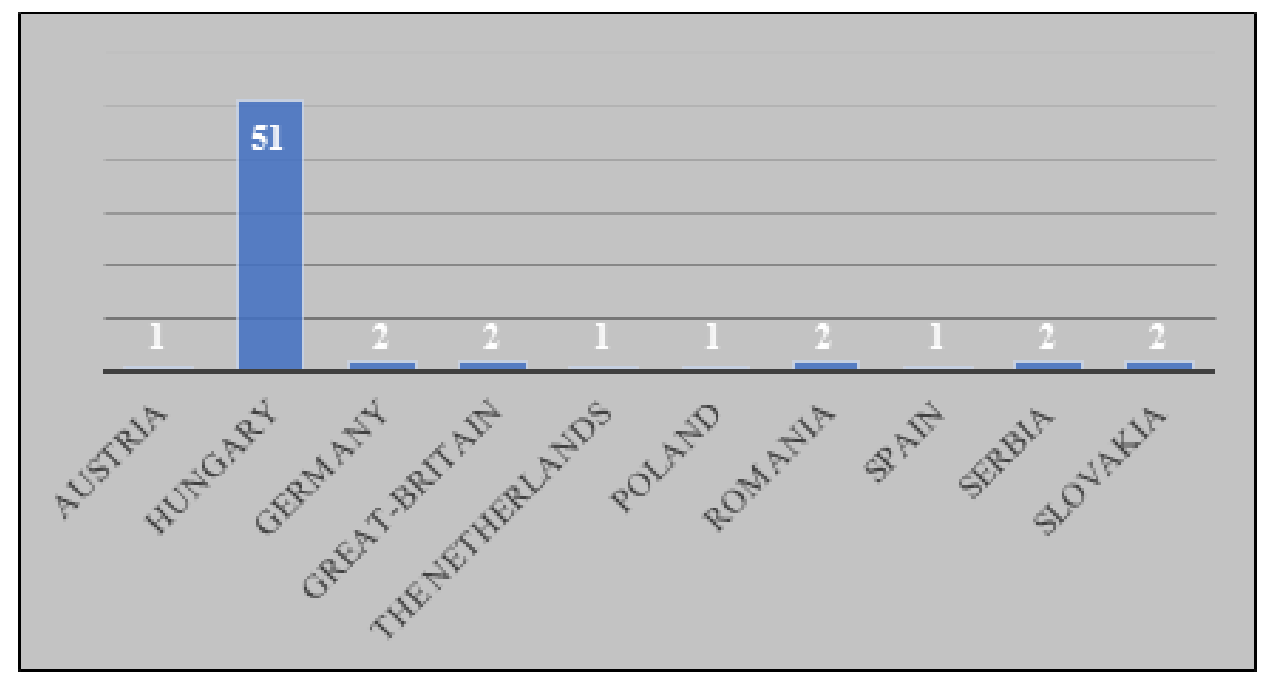

Figure 3. The number of participants based on current place of residence, persons 


\section{Analecta Technica Szegedinensia}

\subsection{The results of the interviews}

\section{The interpretation of the word culture}

As in literature, there are many phrases of the word 'culture', the participants have interpreted the notion of culture very differently, but recurring elements can be perceived, such as traditions, habits, and lifestyles. "Culture is primarily about all of our traditions and customs, including our everyday linguistic expressions, the everyday things that we like to do, the foods we consume, the folk traditions associated with different occasions, and the culture of which is part of people's mentality, what and how do we see it" (Spanish). "It means the traditions and habits of a nation to me: how they live, how they behave, what they do, what their characteristics are in social life and in private, what foods they consume, what their drinks are, what their agenda, and so on" (English). "For me, culture is a way of life that a group of people follows from generation to generation" (Guinean).

Some interviewees believe that culture is a set of traditions inherited from generation to generation. "Culture is a set of habits and traditions that this generation produces and delivers to future generations." Among the interviewees, there were those whose appearance, the look of the culture, is "the habit of others, their dressing, the behaviour and the speech, looks" (Serbian).

\section{Main food types}

The food varieties favored by the interviewees show a very varied picture. However, the participants are eager to eat vegetables, meat and fish. Of course, the local, traditional food is present in the nutrition of almost all participants. At the same time, several interviewees explained that he would like to try other nations' food.

"In my culture, people usually consume fish or some Mediterranean food. I also love fish, rice, meat and vegetables. My family, however, eats any food: we usually eat lots of fish, potatoes, vegetables and pasta. "(Italian)

"For the older generation in the Netherlands it is very important to eat meat every day: one day pork, the next day cattle, then chicken. They eat mostly beef and fish. Typically, olive oil or cooking oil is used to prepare food. The Dutch tradition is the raw herring that is used locally on the market with onions. The typical food on the local market is the fish fillet fried in the flour, with egg-mayonnaise sauce and garlic. The french fries are often eaten with a special spicy ketchup, curry ketchup. Mustard is mainly used for sausages and fascizas. The sausage is made from pork ". (Dutch)

\section{Factors affecting food consumption}

The question of what factors are taken into account in the selection of foods has been the main concern of the interviewees as regards food freshness. Interviewees also considered the quality, taste, smell, texture and color of foods to be important.

"It is very important for meals that the meat and vegetables are fresh. In the case of durable foods, it is important to contain as little sugar as possible and to avoid any coloring matter or additives. "

Another important factor in the selection of foods was origin, expiry date and packaging.

\section{Values in life and food consumption}

During the interviews, the most frequently quoted values were family and health, which the interviewees had repeatedly contacted with food consumption.

"Of course, children are the greatest gift in their lives. In addition, love for nature is very important and health. "They love to walk in nature and play sports, so it's important to be healthy."(Austrian)

"For me, the main value is health and trying to get the maximum out of our lives, the more we get to know the world, the more people we get to know, the exit from our comfort zone." (English) 


\section{Analecta Technica Szegedinensia}

"Family and health. I can clearly emphasize these two things. Both of the values I have formulated are related to food consumption, because we love eating the most together with the family and what food we consume is very important from the health point of view. the most preferred Italian and Spanish cuisine is basically fresh and healthy food, both of which are basically light ingredients. "(Spanish)

In addition to family and health, for others, love, friendship, honesty, truth and respect are the most important values. "good human relations" was also a decisive value for some interviewees.

\section{The role of food and eating in culture}

Many (mainly Far Eastern, African) interviewees show that the quantity and quality of food and food consumed also express social affinity:

"Food plays a very important role in our culture, because it tells us what ethnicity or what denomination it belongs to. Women celebrate more holidays, offer food in large pots, sit around people, and eat by hand. "(Guinea)

"The lack of food is a sign of poverty, and Vietnamese are reluctant to show it. "(Vietnamese)

"Meals are definitely central to Chinese culture and everyday life. I'm Chinese, so I grew up on authentic Chinese food and still eat. My wife is almond, but there is no significant difference in the taste of her and my family's recipes. Perhaps this is because we are both North Chinese, and cultural differences typically come from North-South division, or have a different culture in certain minority areas such as Ujghur Province or Sichuan. "(Chinese)

\section{The relationship between food and culture}

During the interviews, I also examined the experiences of the participants with regard to cultural differences, and the differences between their own culture and the food consumption habits of other nations. In terms of results, I received very different but interesting opinions:

"People's habits are usually determined by their culture, because it shows how their daily life takes place, what they eat, what their religion is, how they behave in certain situations. For example, there are those who shout during a conversation, it was very strange to me. A striking difference is that in many African countries, more people still eat by hand in a pot, and in Europe, everyone eats with their own cutlery. "(Guinea)

"Vietnamese like to eat in large groups while talking long. It is not common in Hungarian culture" (Vietnamese)

"Well, as we talk about food, the kitchen is definitely part of culture, as are many other things like language, humor and the way people usually approach a culture of life. For example, our Italians are much looser, while Hungarians are much more serious! ”(Italian)

"In southern countries, such as Italy, Greece, people are thinking strangely about life: they are not in a hurry, they do not enjoy and enjoy life. "(Polish)

"I can compare Hungary and Portugal. I think people are not as nice here as in my own country. But night life is much better than we do. (Portuguese) "

"In France, people eat very slowly, while the Italian people eat late at night. (Korean). In Korea it is a disgrace if someone speaks while eating. However, in other countries this is completely accepted. "(Korean)

"Every nation and nation has its own habits that can be observed in everyday life, in private life and in the workplace. I do not consider myself a very good observer, but these are usually quite clear and conspicuous things. relatively mixed nation), regularity is important in us, we love the routine, we are not too personal, although it also depends on the personality, but with the Dutch who are loose, direct and much more flexible. Mentoring is very typical for work, while in Switzerland, flexibility is almost an unknown concept. (English living in the Netherlands)" 


\section{Analecta Technica Szegedinensia}

\section{CONCLUSIONS}

In my research, I examined the cultural differences inherent in food consumption through in-depth interviews prepared by university students. In the study, I have applauded the fact that interviewees interpret the notion of culture in a very diverse way, while observing recurring elements in interpreting the concept, such as tradition, customs and lifestyle. It was evident that food plays a very important role in the daily lives of individual nations. At the same time, food and meals serve not only the maintenance of life but also other functions in the society. For example, food can be an expression of belonging to a social class, it also discloses income and expresses identity.

However, I must emphasize that my research was intended for exploratory research with the primary purpose of learning about cultural factors that affect food consumption. On one hand, the results of the research can help marketing professionals to better understand consumer behaviour and, on the other hand, serve as a basis for a later, representative quantitative research.

\section{REFERENCES}

[1] J. Lehota, Marketingkutatás az agrárgazdaságban, Mezőgazda Kiadó, 2001

[2] B. Nagy, Hogyan befolyásolja a kultúra az egészséget? - Táplálkozás, kultúra és egészség, 2017

[3] L. Kárpáti, J. Lehota, Agrármarketing, Debreceni Egyetem Agrár- és Müszaki Tudományok Centruma, Agrárgazdasági és Vidékfejlesztési Kar, 2007, pp. 21-37.

[4] I. Rudnák, A multikulturális környezet kihívásai a magyarországi nagyvállaltok vezetői körében, $\mathrm{PhD}$ értkezés, Szent István Egyetem, Gödöllő. 2010

[5] Á. Hofmeister-Tóth, Fogyasztói magatartás, AULA Kiadó Kft., 2003

[6] Z. Szakály, I. Pallóné Kisérdi, A. Nábádi, Marketing a hagyományos és tájjellegü termékek piacán, Kaposvári Egyetem, Gazdaságtudományi Kar, Kaposvár, 2010 